\title{
Pattern of deliberate self-poisoning cases admitted to Poison Control Center Ain Shams University Hospitals during the years 2015-2016
}

\author{
Hoda M Salah Eldin and Samar A Azim ${ }^{1}$ \\ ${ }^{1}$ Department of Forensic Medicine \& Clinical Toxicology, Faculty of Medicine, Ain Shams University, Cairo, Egypt.
} All right received.

\begin{abstract}
Suicide is one of the leading causes of death worldwide. Deliberate self-poisoning (DSP), is the most common method of attempted suicide and accounts for the majority of suicide-related hospital admissions. The incidence in Egypt tends to be under-estimated.

Aim: Evaluating the pattern of deliberate self-poisoning cases who were admitted to Poison Control Center Ain Shams University Hospitals (PCC-ASUH) from January 2015 to December 2016.

Method: An observational study was conducted including all patients deliberately self-poisoned throughout the study period .Recorded data in the present study included: age, gender, and residence, type of causative agent, severity of poisoning, and mortality.

Results: A total of 10035 and 10758 self-poisoned patients were received in 2015 and 2016 respectively. Results remained similar in both years of the study. Cases were predominantly in the age group between 19 and 30 years, females $69 \%$ and were received from Cairo. Used substances were mainly drugs: centrally-acting drugs ranked first including Tricyclic antidepressants TCA, Benzodiazepines (BZD), antipsychotics and carbamazepine followed by analgesics and cardiopulmonary drugs. Among non-drug agents, organophosphorus insecticides were the most common .Lower number of cases used phosphides, corrosives and detergents, petroleum distillates, phenol and paraphenylenediamine (PPD). The majority of cases were mild $(>70 \%)$ in both years of the study. Severe cases constituted $6.8 \%$ of DSP cases, with overall in-hospital mortality $0.6 \%$. Organophosphorus insecticides topped the agents responsible for mortality followed by unknown drugs with small contributions by other drug and non-drug agents.

Conclusion: Deliberate self-poisoning is a common presentation to PCC-ASUH .General trends show significant predominance of adolescents and young adults especially females, usage of drugs mainly centrally-acting agents, and low case fatality which is mainly in relation to organophosphorus compounds.
\end{abstract}

\section{Introduction}

uicide is a global problem especially in low- and middle-income countries (World Health (DSP), the third leading method of suicide overall, accounts for more than $70 \%$ of all serious suicide attempts. As the most common method of attempted suicide, DSP accounts for $85 \%$ to $95 \%$ of suicide-related hospital admissions. Non-fatal self-poisoning causes hundreds of thousands of emergency room and hospital visits each year and generates substantial costs to the health care system (Albert et al., 2015; Finkelstein et al, 2015).

In 2014, the World Health Organization listed Egypt as among the countries with the lowest suicide rate, at less than five suicides per 100,000 people (World Health Organization, 2014a). Incidence of suicide tends to be under-estimated as suggested by a number of studies. El Mahdy et al., (2010) provided an overview about the incidence of suicidal attempts among teenagers attending the National Egyptian Centre of Environmental and Toxicological Research (NECTR) with a report of 2350 suicidal attempts during a 6 months period. The problem of inadequate surveillance and misclassification was also suggested by Mahmoud et al., (2016) in evaluation of suicidal deaths in Mansoura city from 2009-2014 and reported pesticides and drug overdoses as leading methods regardless of age. Hence, this study aimed at evaluation of deliberate self-poisoning cases 
admitted to Poison Control Center Ain Shams University Hospitals (PCC - ASUH) as the largest tertiary care center in Egypt specialized in management of poisonings from January 2015 to December 2016 as an up-to-date assessment of the demographics, patient characteristics and substances involved in deliberate self-poisoning.

\section{Subject and Method}

This work was conducted as an observational study including all patients deliberately self-poisoned who were admitted to Poison Control Center Ain Shams University Hospitals PCC -ASUH from January 2015 to December 2016. Data were collected after approval of the Research Ethics Committee of Faculty of Medicine Ain Shams University. Also an approval was obtained from the general director of the PCC -ASUH .All data were stored anonymously and confidentiality issues were considered. The collected data was used only for the purpose of the study.

Recorded data in the present study included: age, gender, and residence, type of agent, severity, and mortality. Data collected throughout the study period were tabulated and statistically analyzed using standard SPSS (Standard Package for Social Science) software package, version 20 (Chicago. IL).

\section{Results}

A total of 10035 and 10758 self-poisoned patients were received in 2015 and 2016 respectively. Cases were not evenly distributed across age groups, though remained almost consistent for the entire study period. Almost half of the total number of cases belonged to the age group between 19 and 30 years followed by 12 to 18 years. Incidence declined with increasing age though was still significant above 50 years of age. Female gender constituted about $69 \%$ of cases in both years of the study. According to residence, cases were mainly received from Cairo followed by Kalioubeya and Giza during both years of the study, while a minority of about $5 \%$ of cases lived in more distant governorates. The distribution of age, gender and residence are illustrated in table 1,2 and 3.

Among the toxic agents used for deliberate selfpoisoning, drugs were used in $2 / 3$ of cases, with no marked variation in both years of the study (Table 4). When analyzed by the type of used drugs, centrallyacting drugs ranked first with statistically insignificant difference between 2015 and 2016 (17\% and17.9\% respectively). Among centrally-acting drugs, TCA were used by $5.261 \%$ of cases in 2015 and $6.571 \%$ of cases in 2016.The use of analgesics in DSP was statistically different in both years of the study (12.1\% of cases in 2015 and $11.6 \%$ of cases in 2016).Analgesics included mainly NSAIDs and paracetamol/paracetamol containing cold preparations. Cardiopulmonary drugs constituted about $9 \%$ of causative agents employed in DSP with statistically insignificant difference in both years of the study. Regarding types of cardiovascular drugs, theophylline accounting for 6\% of cases in 2015 and $5.3 \%$ in 2016 followed by $\square$-blockers and antihypertensive drugs (Table 5).

Regarding non-drug agents, organophosphorus insecticides were the most common accounting for $13.9 \%$ and $14.2 \%$ in 2015 and 2016 in comparison to much lower number of cases by phosphides, corrosives and detergents, petroleum distillates, phenol and PPD (Table 6).

According to severity of poisoning, the majority of cases were mild $(>70 \%)$ in both years of the study (Table 7). Severe cases constituted were $6.8 \%$ of DSP cases, with overall in-hospital mortality $0.6 \%$ in both years of the study .Organophosphorus insecticides topped the agents responsible for mortality followed by unknown drugs with small contributions by other drug and non-drug agents. In-hospital mortality and offended agents are illustrated in table (8).

Table (1): Percentage of age distribution of deliberate self-poisoning cases admitted to PCC -ASUH during years 2015-2016.

\begin{tabular}{|c|c|c|c|c|}
\hline \multirow[t]{2}{*}{ Age (years) } & \multicolumn{2}{|l|}{2015} & \multicolumn{2}{|l|}{2016} \\
\hline & No & $\%$ & No & $\%$ \\
\hline $12-18$ & 2800 & 27.9 & 3106 & 28.8 \\
\hline $19-30$ & 4915 & 48.9 & 5178 & 48.1 \\
\hline $31-40$ & 1335 & 13.3 & 1447 & 13.4 \\
\hline $41-50$ & 555 & 5.5 & 565 & 5.3 \\
\hline$>50$ & 430 & 4.3 & 462 & 4.3 \\
\hline Total & \multicolumn{2}{|c|}{10035} & \multicolumn{2}{|c|}{10758} \\
\hline
\end{tabular}

Table (2): Percentage of sex distribution of deliberate self-poisoning cases admitted to PCC -ASUH during years 2015-2016.

\begin{tabular}{|l|l|l|l|l|}
\hline \multirow{2}{*}{ Sex } & \multicolumn{2}{|l|}{2015} & \multicolumn{2}{l|}{2016} \\
\cline { 2 - 5 } & No & \% & No & \% \\
\hline Female & 6921 & 68.96 & 7453 & 69.27 \\
\hline Male & 3114 & 31.03 & 3305 & 30.72 \\
\hline Total & \multicolumn{10035}{|c|}{$\mathbf{1 0 7 5 8}$} \\
\hline
\end{tabular}


Table (3): Percentage of residence of deliberate self-poisoning cases admitted to PCC -ASUH during 2015-2016.

\begin{tabular}{|c|c|c|c|c|c|c|c|}
\hline \multirow[t]{2}{*}{ Region } & \multirow[t]{2}{*}{ Governorates } & \multicolumn{3}{|c|}{2015} & \multicolumn{3}{|c|}{2016} \\
\hline & & No & $\%$ & $\%$ & No & $\%$ & $\%$ \\
\hline \multirow[t]{3}{*}{ Great Cairo } & Cairo & 6828 & 68.04 & \multirow[t]{3}{*}{94.14} & 7436 & 69.1 & \multirow[t]{3}{*}{95.47} \\
\hline & Kalioubeya & 1646 & 15.9 & & 1820 & 16.91 & \\
\hline & Giza & 1026 & 10.20 & & 1018 & 9.46 & \\
\hline \multirow[t]{5}{*}{ Others } & Upper Egypt Governorates & 248 & 2.39 & \multirow[t]{4}{*}{5.149} & 210 & 1.95 & \multirow[t]{4}{*}{5.514} \\
\hline & Other Delta Governorates & 154 & 1.44 & & 138 & 1.28 & \\
\hline & Suez Canal Governorates & 119 & 1.18 & & 128 & 1.12 & \\
\hline & Sinai & 14 & 0.139 & & 8 & 0.164 & \\
\hline & Total & \multicolumn{3}{|c|}{10035} & \multicolumn{3}{|c|}{10758} \\
\hline
\end{tabular}

Table (4): Percentage of type of causative agent in self-poisoning cases admitted to PCC-ASUH during 2015-2016.

\begin{tabular}{|c|c|c|c|c|}
\hline Type & \multicolumn{2}{|l|}{2015} & \multicolumn{2}{|c|}{2016} \\
\hline & No & $\%$ & No & $\%$ \\
\hline Drug & 7509 & 74.82 & 7947 & 73.87 \\
\hline Non-drug & 2526 & 25.17 & 2811 & 26.12 \\
\hline Total & \multicolumn{2}{|c|}{10035} & \multicolumn{2}{|c|}{10758} \\
\hline
\end{tabular}

Table (5): Drugs involved in deliberate self-poisoning cases admitted to PCC -ASUH during years $2015-2016$.

\begin{tabular}{|c|c|c|c|c|c|}
\hline \multirow{2}{*}{\multicolumn{2}{|c|}{ Drugs }} & \multicolumn{2}{|c|}{2015} & \multicolumn{2}{|c|}{2016} \\
\hline & & No & $\%$ & No & $\%$ \\
\hline \multirow{10}{*}{$\begin{array}{l}\text { Centrally } \\
\text { acting } \\
\text { drugs }\end{array}$} & TCA & 528 & 5.261 & 707 & 6.571 \\
\hline & BZD & 398 & 3.966 & 268 & 2.491 \\
\hline & Psychotropic drugs & 355 & 3.537 & 454 & 4.455 \\
\hline & Carbamazepine & 201 & 2.002 & 225 & 2.091 \\
\hline & Tramadol & 140 & 1.395 & 172 & 1.598 \\
\hline & Other antiepileptic & 42 & 0.418 & 36 & 0.334 \\
\hline & SSRI & 28 & 0.279 & 31 & 0.288 \\
\hline & Lithium & 8 & 0.079 & 10 & 0.0929 \\
\hline & Anticholinergic & 8 & 0.079 & 23 & 0.213 \\
\hline & Total & 1708 & $\mathbf{1 7 . 0 2}$ & 1926 & 17.902 \\
\hline \multirow[t]{4}{*}{ Analgesics } & NSAIDs & 675 & 6.726 & 655 & 6.0 \\
\hline & $\begin{array}{l}\text { Paracetamol } \\
\text { +cold preparations }\end{array}$ & 448 & 4.464 & 477 & 4.433 \\
\hline & Salicylate & 93 & 0.926 & 125 & 1.161 \\
\hline & Total & 1216 & 12.116 & 1257 & 11.684 \\
\hline \multirow{6}{*}{$\begin{array}{l}\text { Cardio- } \\
\text { pulmonary } \\
\text { drugs }\end{array}$} & Theophylline & 608 & 6.058 & 571 & 5.3 \\
\hline & Beta blockers & 244 & 2.40 & 281 & 2.6 \\
\hline & Antihypertensive & 112 & 1.11 & 154 & 1.43 \\
\hline & Digoxin & 19 & 0.189 & 23 & 0.213 \\
\hline & $\mathrm{CCB}$ & 2 & 0.0199 & 5 & 0.0464 \\
\hline & Total & 985 & 9.815 & 1034 & 9.611 \\
\hline \multirow[t]{9}{*}{ Miscellaneous } & Unknown & 1863 & 18.565 & 1727 & 16.053 \\
\hline & Antibiotics & 762 & 7.599 & 832 & 8.290 \\
\hline & Antihistamines & 225 & 2.20 & 171 & 1.589 \\
\hline & Anti-diabetic medication & 354 & 3.521 & 398 & 3.78 \\
\hline & Vitamins & 125 & 1.245 & 165 & 1.533 \\
\hline & Metronidazole & 142 & 1.415 & 195 & 1.812 \\
\hline & Miscellaneous & 79 & 0.787 & 173 & 1.608 \\
\hline & OCP & 50 & 0.588 & 69 & 0.641 \\
\hline & Total & 3600 & 35.87 & 3724 & 34.61 \\
\hline Total & & \multicolumn{2}{|c|}{10035} & \multicolumn{2}{|c|}{10758} \\
\hline
\end{tabular}

$T C A=$ tricyclic antidepressants, BZD= benzodiazepines, SSRI=selective serotonin reuptake inhibitors, NSAIDs=nonsteroidal anti-inflammatory drugs, $B B=\beta$-blockers, $C C B=$ calcium channel blockers, OCP= oral contraceptive pills 
Table (6): Non-drug agents involved in self-poisoning cases admitted to PCC-ASUH during 2015-2016.

\begin{tabular}{|c|c|c|c|c|c|}
\hline \multirow{2}{*}{\multicolumn{2}{|c|}{ Type }} & \multicolumn{2}{|l|}{2015} & \multicolumn{2}{|l|}{2016} \\
\hline & & No & $\%$ & No & $\%$ \\
\hline \multirow{2}{*}{$\begin{array}{l}\text { Insecticides } \quad \& \\
\text { Rodenticides }\end{array}$} & Organophosphate insecticides & 1396 & 13.911 & 1531 & 14.23 \\
\hline & Zinc \& aluminum phosphide & 447 & 4.454 & 460 & 4.275 \\
\hline \multirow[t]{5}{*}{ Detergents } & Corrosives & 370 & 3.687 & 475 & 3.950 \\
\hline & Detergents & 179 & 1.783 & 199 & 1.849 \\
\hline & $\begin{array}{lll}\begin{array}{l}\text { Kerosene } \\
\text { distillates }\end{array} & \& \quad \text { petroleum } \\
\end{array}$ & 91 & 0.906 & 103 & 0.957 \\
\hline & Phenol & 32 & 0.318 & 30 & 0.278 \\
\hline & PPD & 11 & 0.109 & 13 & 0.120 \\
\hline \multicolumn{2}{|l|}{ Total } & 2526 & & 2811 & \\
\hline
\end{tabular}

$P P D=$ paraphenylene diamine

Table (7): Poisoning severity for grading deliberate self-poisoning cases admitted to PCC -ASUH during years 2015-2016.

\begin{tabular}{|l|l|l|l|l|}
\hline \multirow{2}{*}{ Degree of severity } & $\mathbf{2 0 1 5}$ & $\mathbf{2 0 1 6}$ & \% \\
\cline { 2 - 5 } & No & \% & No & 74.391 \\
\hline Mild & 7195 & 71.699 & 8003 & 18.767 \\
\hline Moderate & 2154 & 21.464 & 2019 & 6.841 \\
\hline Severe & 686 & 6.836 & 736 & $\mathbf{1 0 7 5 8}$ \\
\hline Total & $\mathbf{1 0 0 3 5}$ & & \\
\hline
\end{tabular}

Table (8): Mortality-related offending agents in deliberate self-poisoning cases admitted to PCC -ASUH during years 2015-2016.

\begin{tabular}{|l|c|c|c|c|}
\hline & \multicolumn{2}{|c|}{$\mathbf{2 0 1 5}$} & \multicolumn{2}{c|}{$\mathbf{2 0 1 6}$} \\
\hline Agent & Number & \% & Number & \% \\
\hline OP & 20 & 33.3 & 27 & 45 \\
\hline Unknown & 13 & 21.6 & 6 & 10 \\
\hline CBZ & 4 & 6.66 & 2 & 3.33 \\
\hline Corrosives & 4 & 6.66 & 2 & 3.33 \\
\hline Phosphide & 3 & 5 & 9 & 15 \\
\hline BZD & 3 & 5 & 0 & 0 \\
\hline Cerebral hemorrhage & 3 & 5 & 0 & 0 \\
\hline TCA & 2 & 3.33 & 4 & 6.66 \\
\hline OHG & 2 & 3.33 & 0 & 0 \\
\hline Lithium & 2 & 3.33 & 2 & 3.33 \\
\hline Tramadol & 1 & 1.6 & 1 & 1.6 \\
\hline Neuroleptics & 1 & 1.6 & 2 & 3.33 \\
\hline BB & 1 & 1.6 & 2 & 3.33 \\
\hline Antihistamines & 1 & 1.6 & 0 & 0 \\
\hline Theophylline & 0 & 0 & 1 & 1.6 \\
\hline PPD & 0 & 0 & 1 & 1.6 \\
\hline Kerosene & 0 & 0 & 1 & 1.6 \\
\hline Total mortality & & $\mathbf{6 0}$ & & $\mathbf{6 0}$ \\
\hline
\end{tabular}

OP: organophosphorus insecticides, BZD: benzodiazepines, TCA: tricyclic antidepressants OHG: oral hypoglycemic drugs, BB: $\beta$ blockers, $P P D=$ paraphenylene diamine

\section{Discussion}

Deliberate self-poisoning is a common presentation to PCC-ASUH considering the high number of cases received every year. The current study provides an important overview of DSP annual trends especially with the limited number of studies on DSP in Egypt and the possible underreported incidence due to cultural and social factors. 
Age distribution among cases of deliberate self-poisoning was similar during years 2015 and 2016.The peak age group for both genders was 19 to 30 years followed by 12 to 18 years. The current study demonstrates that deliberate self-poisoning is a predominant problem in adolescents and young adults. Increased risk of suicidal ideation and behavior was attributed to a wide range of biological, social and environmental factors; including cognitive immaturity, age-related amplified impulsivity, stressful life events, pubertal onset of depression, low parental monitoring, and risk behavior such as substance abuse (King et al, 2001; Dervic et al., 2008; Hills et al., 2009)

Despite a declining percentage of DSP presentations with age, a notable number of cases occurred over the age of 50. Older adults generally report fewer self-harming behavior despite higher completed suicide rates. Increased mental fragility, psychiatric and medical morbidities in addition to access to multiple prescription medications can be considered as potential vulnerabilities of old age (Gavrielatos et al, 2006; Van Orden \&Conwell, 2015; Segal et al, 2016).

Predominance of females among cases of deliberate self-poisoning was found in the present study during both years of the study. Similarly, previous studies demonstrated gender differences in suicide-related behaviors and showed that females are more likely to attempt suicide by poisoning compared to males who are more likely to use higher violence and lethality methods (Callanan \& Davis, 2012; Karch et al, 2012).However, different trends with male predominance were noted in Asia (Raesha et al, 2009; Nguyen et al, 2010; Rajapakse et al, 2013).

Although ASU-PCC receives cases from all governorates as the largest tertiary care center in Egypt for management of poisonings, the majority of cases in the current study were residents of Cairo and nearby governorates. This may reflect an increased rate of suicide in more urbanized areas in comparison to rural areas. Urban-rural differences in suicide rate may relate to the prevalence of psychiatric comorbidities, physical illnesses, and exposure to risk behaviors and psychological stressors accompanying the increased density and diversity of city populations (Qin, 2005). Moreover, as admitted by Khan and Hyder (2006), socio-cultural barriers may limit both seeking medical care and proper reporting of cases from rural areas.

Substances implicated in deliberate selfpoisonings were principally drugs during both years 2015 and 2016.Among used drugs, centrally-acting drugs topped the list including TCA, BZD, antipsychotics and carbamazepine. Interestingly, 90\% of suicide completers and attempters meet the criteria for a diagnosable psychiatric illness and psychiatric patients have a greater number of prescribed drugs in comparison to the general population. Thus availability and accessibility, especially through prescription, might be an important motivation to the choice of psychotropic drugs for DSP providing potential explanation to these results (Haw et al, 2001; Tournier et al, 2009; Gjelsvik et al; 2012).

Despite lower number of cases compared to other centrally acting drugs, the use of tramadol in DSP cannot be overlooked especially with the observed increase in 2016 compared to 2015. Data indicates a growing number of tramadol abusers, in some Middle East countries including Egypt leading to up-scheduling in 2009 (World Health Organization, 2014b). According to Loffredo et al., (2015) tramadol was the most commonly abused pharmaceutical drug among Egyptian youth.

Possible mediators of the association between SUD and suicide were postulated. Factors increasing the chances of acting on suicidal thoughts in cases of SUD may include aggressive-impulsive traits, associated mood disorders, cognitive difficulties leading to a maladaptive way of managing painful feelings and associated neurobiological factors such as abnormal serotonin function (Maser et al., 2002, Pettinati et al., 2002, HarkavyFriedmanetal., 2006; Subletteetal.,2009; Oquendoetal.,2010).

Expert Committee on Drug Dependence, World Health Organization.

Thirty-sixth meeting of the Expert Committee on Drug Dependence-

Tramadol Update Review Report Agenda item 6.1.2014. Geneva,

Switzerland: World Health Organization; 2014

Expert Committee on Drug Dependence, World Health Organization.

Thirty-sixth meeting of the Expert Committee on Drug Dependence-

Tramadol Update Review Report Agenda item 6.1.2014. Geneva,

Switzerland: World Health Organization; 2014

Expert Committee on Drug Dependence, World

Health Organization.

Thirty-sixth meeting of the Expert Committee on Drug Dependence-

Tramadol Update Review Report Agenda item 6.1.2014. Geneva,

Switzerland: World Health Organization; 2014

Findings in the current study, suggest that analgesics were commonly employed in DSP. The used analgesics were mainly NSAIDs and paracetamol/paracetamol containing cold 
preparations. This may be attributed to their availability and the presence of household stocks. Additionally, the status of non-opioid analgesics as non-prescription preparations may imply that it is less likely to be fatal in overdose .This might be an important motivation for choosing them in cases of non-suicidal self-poisoning which can be viewed as a type of self-harm behaviors not associated with intent to die (Heilbron et al.,2010; Zerbo \& Kondracke, 2014).

Basic trends of poisoning generally shows a regional variation related to availability and frequency of prescription, it was not surprising in the present study to record cases of DSP with cardiopulmonary drugs including mainly theophylline, B-Blockers and antihypertensive drugs. Equivalently, reports of theophylline poisoning in Egypt are still recorded to date (El Masry\& Tawfik, 2013; Hammad et al., 2014;Tawfik\& Khalifa,2017).This is in contrast to the noted marked decrease of documented toxic exposures over the past decade which reflects the diminishing use of theophylline for management of asthma (Mowry et al., 2015).

Possible explanations of the increased availability of antihypertensive agents for overdose include the high incidence of hypertension in adult population in Egypt $(26.3 \%)$ and an expanded use of beta-blockers in various disorders beside their traditional use in treating hypertension (WHO\& ARE-Ministry of Health\& Population,2012; Mowry et al., 2015).

The current study showed statistically insignificant difference between 2015 and 2016 regarding the percentage of cases using centrally acting and cardiopulmonary drugs. The distribution of drugs used for DSP in our study was comparable to previous reports in France, Belgium, and Germany where psychotropic drugs, especially benzodiazepines and antidepressants, ranked first. On the other hand, paracetamol was the most common substance used in DSP in Turkey, US and UK. (Xiang et al, 2012; Hendrix et al., 2013;Bailey\& Wisniacki, 2014; Ekingen et al., 2015 ; Sorge et al., 2015 ; Beaune et al.,2016).

Regarding non-drug agents, statistically insignificant difference between 2015 and 2016 was also noted. Organophosphorus insecticides were the most common non-drug agents followed by phosphides, corrosives and detergents. Less number of cases used petroleum distillates, phenol and PPD. Agricultural pesticides is responsible for third of the global burden of suicide (World Health Organization, 2014a) .The widespread use of household chemicals among agents used for DSP is plausible, owing to their availability in the domestic environment, widespread use, and relatively cheap price (Basher et al., 2015).

Although severe cases constituted $6.8 \%$ of cases in both years, almost all DSP patients survived their hospital stay with overall in-hospital mortality $0.6 \%$ in both years of the study. This relatively low case fatality for self-poisoning was similarly noted (Heyerdahl et al., 2009; Schwake et al., 2009; Okumura et al., 2012).However, the situation may be different in studies performed in rural Asia .Different characteristics of the ingested agent, demographics and cultural and ethnic backgrounds are among the contributing factors to adverse clinical course and higher incidence of fatality (Eddleston et al., 2005; Shokrzadeh et al., 2017).

Of the total number of cases of DSP during years 2015-2016, mortalities were mainly related to organophosphorus compounds followed by unknown drugs. As organophosphorus poisoning is one of the most common causes of worldwide poisoning fatalities, these results can be justified. This considerable mortality is mostly attributed to respiratory failure occurring in into two overlapping clinical syndromes: acute cholinergic respiratory failure and intermediate syndrome. Early respiratory failure during the acute cholinergic crisis may involve central respiratory depression, respiratory muscle weakness, and direct pulmonary effects (bronchospasm and bronchorrhoea). On the other hand, delayed failure may be due to respiratory muscle weakness. Cardiovascular effects are also potentially fatal. The possible mechanisms of cardiac toxicity include sympathetic and parasympathetic over-activity, hypoxemia, acidosis, electrolyte derangements and a direct toxic effect on myocardium. Further deaths can be related to prehospital disturbed level of consciousness such as aspiration and anoxic brain damage (Carey et al., 2013; Chowdhary et al., 2014; Laudari et al., 2014; Javed et al., 2016)

Additionally, mortalities related to unknown drugs may reflect the challenging management of poisoning when the characteristics and clinical course of the toxic exposure are unknown. This may be associated with delayed intensive treatments and failure to recognize the potential for serious or delayed toxic effects (Enfield \& Kirk, 2014).

\section{Conclusion and recommendation}

Low fatality of deliberate self-poisoning raises the possibility to focus on preventive measures. Further studies are needed to identify trends of deliberate self-poisoning national wide and hence implement strategies for clinical prediction, identification of cases at risk and appropriate intervention. Longitudinal surveillance and psychiatric consultation are also strongly suggested to relate the 
first episode of DSP to subsequent suicide and premature death and its role as a predictive factor.

\section{References}

Albert M, McCaig LF and Uddin S (2015): Emergency department visits for drug poisoning: United States, 2008-2011. NCHS data brief, no. 196. National Center for Health Statistics, Hyattsville (MD):1-8.

Bailey G and Wisniacki F (2014): One Year of Deliberate Self-poisoning Presentations at a West London Emergency Department. West London Medical Journal, 6(1):23-8.

Basher F, Kumar A, Rajesh NB, et al., (2015): Gender Differences in Risk Factors and Patterns Contributing Towards Deliberate SelfPoisoning. Annals of Abbasi Shaheed Hospital \& Karachi Medical \& Dental College, 20(1):23-8

Beaune S, Juvin P, Beauchet A et al., (2016): Deliberate drug poisonings admitted to an emergency department in Paris area-a descriptive study and assessment of risk factors for intensive care admission. European review for medical and pharmacological sciences, 20(6):1174-9.

Beautrais AL (2000): Risk factors for suicide and attempted suicide among young people. Australian \& New Zealand Journal of Psychiatry, 34(3):420-36.

Callanan VJ and Davis MS (2012): Gender differences in suicide methods. Soc Psychiatry Psychiatr Epidemiol. 47:857-869.

Carey JL, Dunn C and Gaspari RJ (2013): Central respiratory failure during acute organophosphate poisoning. Respiratory physiology \& neurobiology, 189(2):403-10.

Chowdhary S, Bhattacharyya R and Banerjee D (2014): Acute organophosphorus poisoning. Clinica chimica acta, 431:66-76.

Dervic K, Brent DA and Oquendo MA (2008): Completed suicide in childhood. Psychiatric Clinics of North America, 31(2):271-91.

Eddleston M, Gunnell D, Karunaratne A et al., (2005): Epidemiology of intentional self-poisoning in rural Sri Lanka. The British Journal of Psychiatry, 187(6):583-4.

Ekingen E, Göktekin MÇ, Ardiç S et al., (2015): Retrospective analysis of suicide attempt with analgesics. Journal of Academic Emergency Medicine,14(4):172-6.

El Mahdy NM, Radwan NM and Soliman EF (2010): Suicidal attempts among children and teenagers in EGYPT. Egyptian Journal of Occupational Medicine, 34(2):153-70.

El Masry MK and Tawfik HM (2013): 2011Annual Report of the Poison Control Centre of Ain Shams University Hospital, Cairo, Egypt. Ain Shams Journal of Forensic Medicine and Clinical Toxicology, 20:10-7.
Enfield KB and Kirk MA (2014): Use of the intensive care unit In : Goldfrank's Toxicologic Emergencies, Hoffman RS, Howland MA, Lewin NA, et al.(eds.), $10^{\text {th }}$ ed, McGraw Hill Professional, USA. PART A: The general approach of medical toxicology. p135-142.

Finkelstein Y, Macdonald EM, Hollands S et al., (2015): Risk of suicide following deliberate selfpoisoning. JAMA psychiatry, 72(6):570-5.

Gavrielatos G, Komitopoulos N, Kanellos P et al., (2006): Suicidal attempts by prescription drug overdose in the elderly: a study of 44 cases. Neuropsychiatric Disease and Treatment, 2(3), 359-363.

Gjelsvik B, Heyerdahl F and Hawton K (2012): Prescribed medication availability and deliberate self-poisoning: a longitudinal study. The Journal of clinical psychiatry, 73(4):e54854.

Hammad SA, Amin SA, El-Seidy AM et al., (2014): Clinical study of poisoned cases by some drugs admitted to the Menoufia poisoning control center over 1 year (2011), with a focus on ECG changes. Menoufia Med J . 27:260-8

Harkavy-Friedman JM, Keilp JG, Grunebaum MF et al., (2006): Are BPI and BPII suicide attempters distinct neuropsychologically? Journal of Affective Disorders, 94(1):255-9.

Haw C, Hawton K, Houston K et al., (2001): Psychiatric and personality disorders in deliberate selfharm patients. The British Journal of Psychiatry, 178(1):48-54.

Heilbron N, Compton JS, Daniel SS et al., (2010): The Problematic Label of Suicide Gesture: Alternatives for Clinical Research and Practice. Prof Psychol Res Pr. 41(3): 221-227.

Hendrix L, Verelst S, Desruelles D et al., (2013): Deliberate self-poisoning: characteristics of patients and impact on the emergency department of a large university hospital. Emerg Med J. 30(1):e9.

Heyerdahl F, Bjornaas MA, Dahl R et al., (2009): Repetition of acute poisoning in Oslo: 1-year prospective study. The British journal of psychiatry: the journal of mental science, 194:73-9.

Hills AL, Afifi TO, Cox BJ et al., (2009): Externalizing psychopathology and risk for suicide attempt: cross-sectional and longitudinal findings from the Baltimore Epidemiologic Catchment Area Study. The Journal of nervous and mental disease, 197(5):293-7.

Javed A, Waqar F, Ahmed S et al., (2016): Different patterns of ECG in organophosphate poisoning and effect on mortality. Pakistan Heart Journal, 49(3):121-125.

Karch DL, Logan J, McDaniel D et al., (2012): Surveillance for violent deaths-National 
Violent Death Reporting System, 16 states, 2009. MMWR Surveill Summ. 61: 1-43.

Khan MM and Hyder A (2006): Suicides in the developing world: a case study from Pakistan. Suicide Life Threat Behav. 36(1):76-81.

King RA, Schwab-Stone M, Flisher AJ et al., (2001): Psychosocial and risk behavior correlates of youth suicide attempts and suicidal ideation. Journal of the American Academy of Child \& Adolescent Psychiatry, 40(7):837-46.

Laudari S, Patowary BS, Sharma SK et al., (2014): Cardiovascular Effects of Acute Organophosphate Poisoning. Asia Pacific Journal of Medical Toxicology, 3(2):64-7.

Loffredo CA, Boulos DN, Saleh DA et al., (2015): Substance use by Egyptian youth: current patterns and potential avenues for prevention. Substance use \& misuse, 50(5):609-18.

Madhavan I, Santhosh LK and Thomas V (2015): Clinical Profile and Outcome of Deliberate Self Poisoning Cases in Medical Wards. American Journal of Internal Medicine, 3(61):5-9.

Mahmoud EH, Elmorsy EM, Shahda M et al., (2016): Psychiatric analysis of suicide completers in Mansoura city. Middle East Journal of Psychiatry and Alzheimers, 7 (1):20-7.

Maser JD, Akiskal HS, Schettler P et al., (2002): Can temperament identify affectively ill patients who engage in lethal or near-lethal suicidal behavior? A 14-year prospective study. Suicide and Life-Threatening Behavior, 32(1):10-32.

Mowry JB, Spyker DA, Brooks DE et al., (2015): 2014Annual Report of the American Association of Poison Control Centers' National Poison Data System (NPDS): 32nd Annual Report. Clin Toxicol (Phila). 53 (10):962-1147.

Nguyen TV, Dalman C, Le TC et al., (2010): Suicide attempt in a rural area of Vietnam: Incidence, methods used and access to mental health care. Int J Ment Health Syst. 4(3):1-6.

Okumura Y, Shimizu S, Ishikawa KB et al., (2012): Comparison of emergency hospital admissions for drug poisoning and major diseases: a retrospective observational study using a nationwide administrative discharge database. BMJ open, 2:e001857.

Oquendo MA, Currier D, Liu S et al., (2010): Increased risk for suicidal behavior in comorbid bipolar disorder and alcohol use disorders. The Journal of clinical psychiatry, 71(7):902-909.

Pettinati HM, Kranzler HR and Madaras J (2002): The status of serotonin-selective pharmacotherapy in the treatment of alcohol dependence: In Recent Developments in Alcoholism. Galanter $\mathrm{M}$ et al. (eds.) Springer US. Vol 16. pp. 247262
Qin P (2005): Suicide risk in relation to level of urbanicity - a population-based linkage study International Journal of Epidemiology, 34: 846-852

Rajapakse T, Griffiths KM and Christensen H (2013): Characteristics of non-fatal self-poisoning in Sri Lanka: a systematic review. BMC Public Health, 13:331-346.

Ramesha KN, Rao KBH and Kumar GS (2009): Pattern and outcome of acute poisoning cases in a tertiary care hospital in Karnataka, India. Indian J Crit Care Med.13 (3):152-155.

Schwake L, Wollenschläger I, Stremmel W et al., (2009): Adverse drug reactions and deliberate self-poisoning as cause of admission to the intensive care unit: a 1-year prospective observational cohort study. Intensive Care Medicine, 35:266-74

Segal DL, Connella A, Miller T et al., (2016): Deliberate self-harm among younger and older adults. Death studies, 40(7):440-4.

Shokrzadeh M, Hoseinpoor R, Hajimohammadi A et al., (2017): Pattern of Deliberate Self-Poisoning in Gorgan, North of Iran. International Journal of Medical Toxicology and Forensic Medicine, 7(1):6-18.

Sorge M, Weidhase L, Bernhard M et al., (2015): Selfpoisoning in the acute care medicine 20052012. Der Anaesthesist, 64(6):456-62.

Sublette ME, Carballo JJ, Moreno C et al., (2009): Substance use disorders and suicide attempts in bipolar subtypes. Journal of psychiatric research, 43(3):230-8.

Suokas JT, Suominen K, Heilä H et al., (2011): Attempted suicide in mental disorders in young adulthood. Social psychiatry and psychiatric epidemiology, 46(10):965-74.

Tawfik HM and Khalifa EA (2017): 2015 Annual Report of the Poison Control Centre of Ain Shams University Hospital, Cairo, Egypt. Ain Shams Journal of Forensic Medicine and Clinical Toxicology, 29: 68-

Tournier M, Grolleau A, Cougnard A et al., (2009): Factors associated with choice of psychotropic drugs used for intentional drug overdose. European archives of psychiatry and clinical neuroscience, 259(2):86.

Van Orden K A and Conwell Y (2015). Issues in research on aging and suicide. Aging \& Mental Health, 20, 240-251.

Vijayakumar L, Kumar MS and Vijayakumar V (2011): Substance use and suicide. Current opinion in psychiatry, 24(3):197-202.

WHO and ARE-Ministry of Health\& Population (2012): Egypt National STEPwise Survey of Non Communicable Diseases Risk Factors 20112012. 
World Health Organization (2014) a: Preventing suicide: a global imperative .Available on the WHO website (www.who.int)

World Health Organization (2014) b: Tramadol Update Review Report Agenda item .Thirty-sixth meeting of the Expert Committee on Drug Dependence, Geneva, Switzerland. Available on the WHO website (www.who.int)

Xiang Y, Zhao W, Xiang H et al., (2012): ED visits for drug-related poisoning in the United States,
2007. The American journal of emergency medicine, 30(2):293-301.

Zerbo EA and Kondracke AM (2014): Psychiatric principles In : Goldfrank's Toxicologic Emergencies, Hoffman RS, Howland MA, Lewin NA, et al., (eds.), $10^{\text {th }}$ ed, McGraw Hill Professional, USA. 10e PART B: The fundamental principles of medical toxicology.pp341-355.

الملخص العربيى

نمط حالات التسمم الذاتي المتعمد النى أدخلت بمركز علاج التسمم بمستشفيات جامعة عين شمس خلال

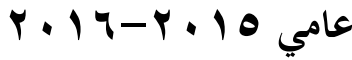

\section{هاى محمد صلاح الدين عبد العزيز و سمر عبدالعظيم}

يعتبر الانتحار واحداً من الأسباب الرئيسية للوفاة على مستوى العالم كما يعتبر التسمم الذاتي المتعمد الأسلوب الأكثر شيوعا لمحاولة

الانتحار فضلاً عن كونه سبباً لغالبية حالات دخول المستشفى المرتبطة بالانتحار، ويميل تقييم المعدل في مصر إلى الميلى القصور.

الهدف من الدراسة: تقييم النمط الخاص بحالات التسمم الذاتي المتعمد الذين تم حجزهم في مركز علاج التسمم بمستشفيات

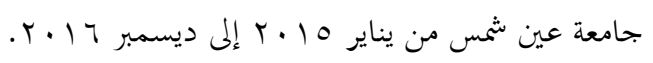

المنهج: أجريت دراسة رصدية شملت جميع حالات المرضى الذين تعرضوا للتسمم الذاتي المتعمد طوال فترة الدراسة. واشتملت

$$
\text { البيانات المسجلة في هذه الدراسة على: العمر والجنس والإقامة ونوع المسبب وشدة التسمم والوفيات. }
$$

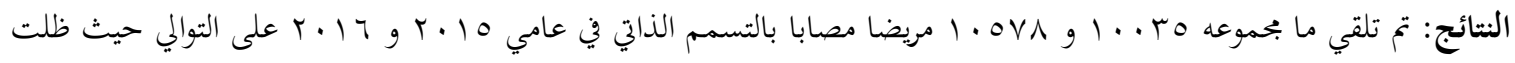

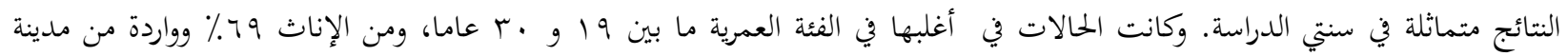
القاهرة. وكانت المواد المستخدمة من الأدوية بشكل أساسى حيث أحتلت الادوية المؤثرة على الجهاز العصبى المرتبة الأولى وتضم مضادادات

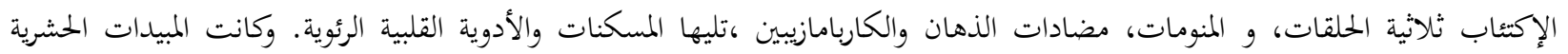
العضوية الفوسفاتية هي الأكثر شيوعا بين العوامل الغير دوائية، مقارنة بعدد أقل من الحالات المستخدمِة للفوسفينات، والمواد الكاوية والمنظفات،

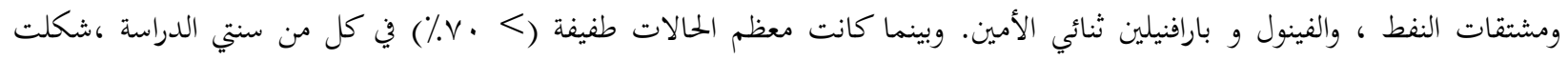

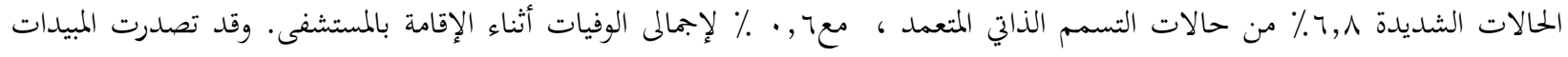
الحشرية الفسفورية العضوية العوامل المسؤولة عن الوفيات، وتلاها العقاقير الغير معروفة مع نسب صغيرة من العوامل الدوائية و الغير دوائية

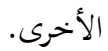

الخحلاصة: يعتبرالتسمم الذاتي المتعمد عرضاً شائعاً بمركز علاج التسمم بمستشفيات جامعة عين شمس و تظهر الإتحاهات العامة غلبة

المراهقين وصغار البالغين وخصوصاً الإناث، واستخدام العوامل الدوائية خاصة المؤثرة على الجهاز العصبى ، وانخفاض الوفيات الناجمة و ارتباطها لئهات بشكل رئيسي بالمركبات الفسفورية العضوية. ا قسم الطب الثر عي والسموم- كليه الطب ، جامعه عين شمس - القاهرة - مصر 